\title{
Estimates and Analysis of the Reference Evapotranspiration in Gassol, Taraba State
}

\author{
Ochoche G. ${ }^{1, *}$ and Odeh C. I. ${ }^{2}$ \\ ${ }^{1,2}$ Department of Physics, Taraba State University, Jalingo, Taraba State, Nigeria \\ Corresponding Author: *ehiely@gmail.com
}

\begin{abstract}
Reference evapotranspiration is very important because it correlates with the amount of water required by crops and also plays very key role in the hydrological cycle. Evaporation is the process of water loss from the earth surface in which temperature effect is significant while transpiration is water loss from plants. Studying evapotranspiration is also important because of the link between climate change and water scarcity. The reference evapotranspiration for Gassol was estimated and analysis done to observe its trend and variation. In this paper, the FAO Penmann-Monteith model was used to estimate the reference evapotranspiration for Gassol town located in the Sudan Savannah vegetation belt of Nigeria. The annual monthly estimates show a generally recurring seasonal pattern of variation from 1985 to 1991. January through June had lower $E T_{0}$ compared to July through December. The time series plot of the ET $T_{0}$ estimates from 1985 to 1991 in monthly renditions gives a cyclical pattern of variability with most of the years showing bimodal peaks. Also, an evenly spread data was presented by the normal distribution curve. The periodogram of the estimated reference evapotranspiration gave a dominant periodicity of 9.33 months cycle. The estimates of and the pattern of variation of the reference evapotranspiration as observed for Gassol in this study will very likely experience a continuous downward trend. For proper irrigation management, January to March and October to December should be properly planned.
\end{abstract}

Keywords: Reference evapotranspiration, Irrigation, Water budget, FAO Penmann-Monteith, Hydrology, Variation

\subsection{Introduction}

In hydrology and meteorology, evapotranspiration is of immense importance. Different methods of its study were developed as a result of its complex nature both as a biological and a physical process (Rácz et al. 2013). The crisis of shortage of water due to high demand for agricultural and industrial applications as well as general societal use in developed and developing cities, are responsible for high pressure on irrigation agriculture practice (Abegunrin et al., 2015). Eruola et al. (2012) studied the application of "rainfall-potential" evapotranspiration model to the production of yam. At different stages of the research they measured indices for growth and its influence on the yield of tuber. The major role evapotranspiration plays in the hydrological cycle led to its inclusion in environment based models for water budgeting, function of yield, scheduling of irrigation, rainfall index, etc. (Wang et al., 2009). According to Ingale et al. (2015), timely and accurate estimates of reference evapotranspiration is a necessity if policies governing irrigation schemes must be effectively planned and executed. They also posited that in order to gain optimum productivity and crop yield, efficient utilization of water is necessary.

A phenomenon that poses great threat to food security particularly in the semiarid regions of Africa is draught and its attendant consequences like disease incidence. Loss of livestock and general hardship for rural dwellers will inform the suitability of developing a model for the prediction of reference evapotranspiration (Umara et al., 2012). Evapotranspiration takes place as water from plant surface escapes to the atmosphere by transpiration and from the soil through evaporation, where temperature plays a significant role (Edoga and Suzzy, 2008). In order to compute precisely crop water usage, it is 
important to determine accurately the reference evapotranspiration. Developing countries are faced with the challenge of scarcity of water that can be linked to climate change, high water demand and environmental degradation (Adeboye et al., 2009). Increased population for countries that are developing comes with the demand for adequate water (Ufoegbune et al., 2011). There is a proportional relationship between evapotranspiration and water required by crop. A proper understanding of evapotranspiration aids in design and implementation of irrigation facilities and their upkeep (Bernadette et al., 2014). Alhassan et al. (2015) worked on the scheduling of irrigation and required water for tomato in the guinea savanna zone of Nigeria by applying the FAO-CROPWAT model.

Water is lost through evapotranspiration from different bodies of water including snow cover and equally water loss occurs through transpiration from plants. In order to estimate evapotranspiration it is fundamental to first calculate the reference evapotranspiration. The model has factors like wind speed, solar radiation, etc. The current extremes experienced in rainfall regimes alongside population growth in Nigeria inform the need for improvement in water management to boost food production (Chineke et al., 2011). Water use efficiency requires optimizing and maximizing water use through determining the actual water required by the crops (Rauf and Shittu, 2015). Water availability is a factor that determines crop productivity. In crop nourishment, water use is therefore of immense importance (Edoga, 2007). Adeleke et al. (2015) states that ground water is a system that comes to fore in the study of climate, hydrology and hydrogeology. They used the CROPWAT 8.0 software and different other models for estimating evapotranspiration in their work on ground water recharge in Odeda, Nigeria. The objective of this study is to specifically obtain estimates for the reference evapotranspiration for Gassol using the FAO Penmann-Monteith model and generally carry out analysis for these estimates to observe trends and pattern for each year of study.

\subsection{Materials and Methods}

\subsection{Description of the study area}

The study area is Gassol Local Government area located in the central zone of Taraba State. It falls within the Sudan Savannah vegetation belt of Nigeria with an estimated annual rainfall range of 500 $\mathrm{mm}$ to $1000 \mathrm{~mm}$, according to Adekola et al. (2015). Gassol is characterized by the following coordinates Latitude $8^{\circ} 38^{\prime} 00^{\prime \prime}$ North and Longitude $10^{\circ} 46^{\prime} 00^{\prime \prime}$ East as shown in Figure 1.

\subsection{Data source and analysis}

The data for this research was obtained from the Upper Benue River Basin Development Authority of the Federal Ministry of Water resources. It contains minimum temperature, maximum temperature, relative humidity, wind speed and sunshine hours for 1985 to 1991. The FAO Penman-Monteith model for estimating the reference evapotranspiration $E T_{0, P}{ }_{M}$ was used as given by Equation 1 (Edebetu et al., 2014; Ogolo, 2014; Maina et al., 2014; Edebetu, 2015).

$$
E T_{0, P M}=\frac{0.408 \Delta\left(R_{n}-G\right)+\gamma \frac{37}{T+273} U_{2}\left\{e_{s}-e_{a}\right\}}{\Delta+\gamma\left[1+0.34 U_{2}\right.}
$$

Where:

$E T_{0}$

$R_{n}$

$G$

$T$

$e_{s}$

$e_{a}$

$\left(e_{s}-e_{a}\right)$

$\Delta$

$\gamma$
Reference evapotranspiration in mmday ${ }^{-1}$

Net radiation value at the crop surface $\mathrm{MJm}^{-2} \mathrm{~d}^{-1}$

Soil heat flux density $\mathrm{MJm}^{-2} \mathrm{~d}^{-1}$

Mean daily air temperature

Saturation vapour pressure $(\mathrm{KPa})$

Actual vapour pressure $(\mathrm{KPa})$

Pressure deficit $(\mathrm{KPa})$

Slope of the saturation vapour pressure-temperature curve $\left(\mathrm{KPa} /{ }^{\circ} \mathrm{C}\right)$

Psychometric constant $\left(\mathrm{KPa} /{ }^{\circ} \mathrm{C}\right)$ 


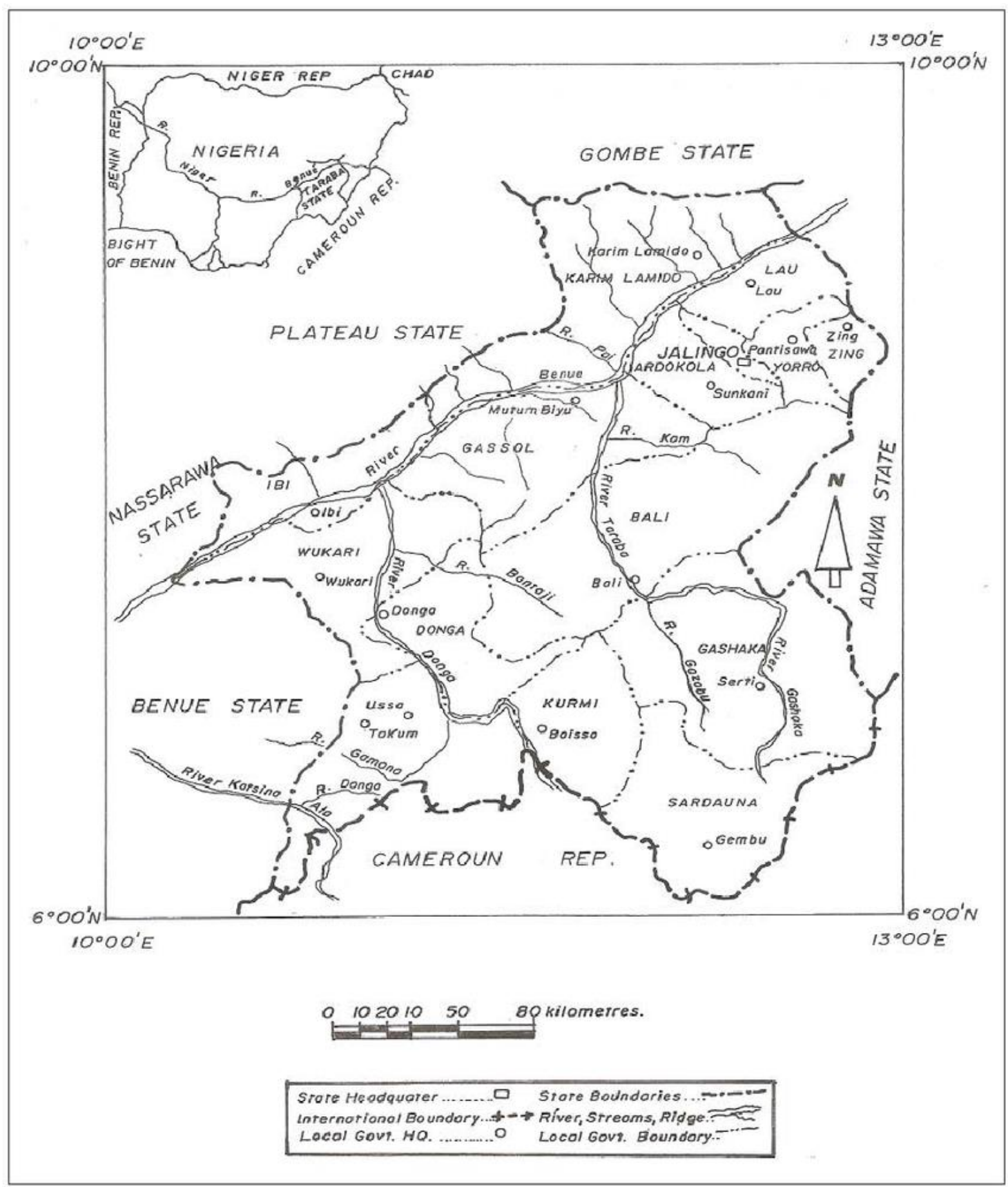

Figure 1: Map of Taraba State showing the sixteen Local Government Areas Gassol inclusive

\subsection{Results and Discussion}

The following charts are results of the analysis of the reference evapotranspiration for Gassol using FAO CROPWAT 8.0.

Figure 2 shows the estimated reference evapotranspiration of the study area for the year 1985. It contains the monthly variation and has a maximum of 5.80 mmday $^{-1}$ in February while the minimum was in the month of August with a quantity of 3.93 mmday $^{-1}$. A gentle decreasing trend was observed for the entire year. The annual average was 4.75 mmday $^{-1}$ as similarly obtained by Alhassan et al. (2015). The first half of the year had higher $E T_{0}$ than the second half. The months of July and August experienced deviations below the annual mean value of the estimated reference evapotranspiration but not significant to affect the entire estimate. As clearly seen on the chart July and August had lower 
$E T_{0}$ values compared to the other months. This might be due to lower temperature experienced in those months as corroborated by Edoga and Suzy (2008).

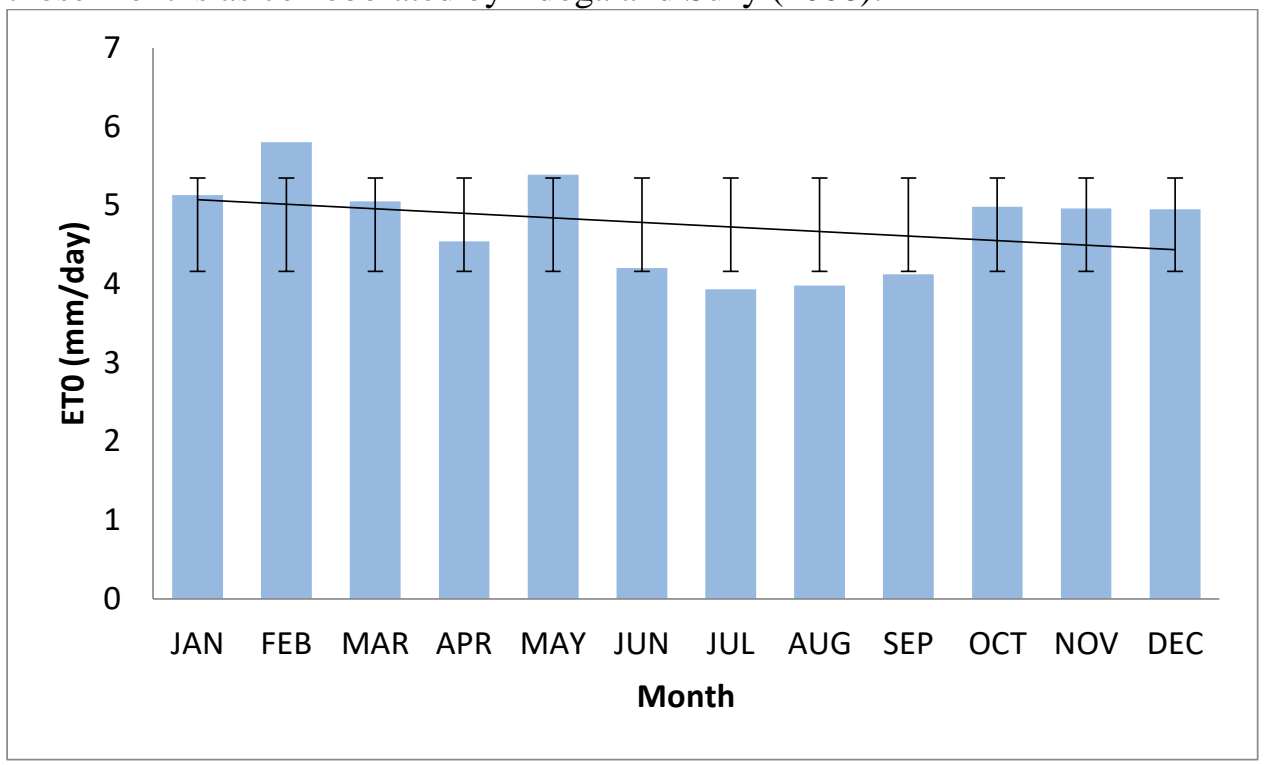

Figure 2: Gassol monthly evapotranspiration and standard deviation for 1985

Figure 3 is the estimated reference evapotranspiration for the year 1986. December had the minimum of 4.25 mmday $^{-1}$ while the maximum value of 6.36 mmday $^{-1}$ was in April. The annual average $E T_{0}$ for the year was 5.11 mmday $^{-1}$ with a steep decreasing trend as the first half of the year experienced higher $E T_{0}$ values. July had value below the annual mean and therefore not significant as to affect the entire estimate. The trend implies that changing pattern decreased from January to December while peak rainfall months of July and August experienced lower values of $E T_{0}$.

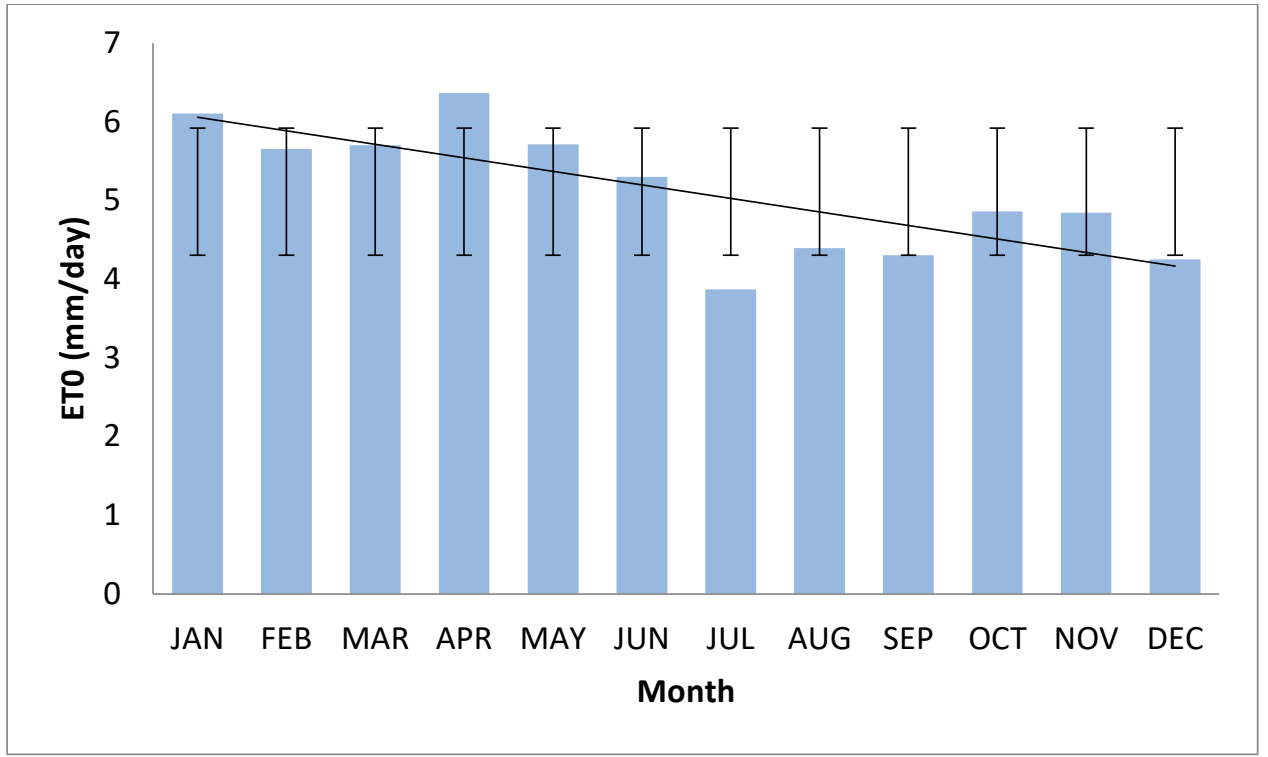

Figure 3: Gassol monthly evapotranspiration and standard deviation for 1986

Figure 4 shows the estimate of reference evapotranspiration for the study area. The minimum of 4.30 mmday $^{-1}$ was in August while May had the maximum of 6.52 mmday $^{-1}$. The annual average was 5.29 mmday $^{-1}$. These are similar to Umara et al. (2012). Also, the first half of the year experienced higher $E T_{0}$ than the second half of the year. The year equally had decreasing trend. Only the month of August experienced deviations below the annual mean estimate. This implies that the estimates are within acceptable range for the FAO Penmann-Moneith model used. 


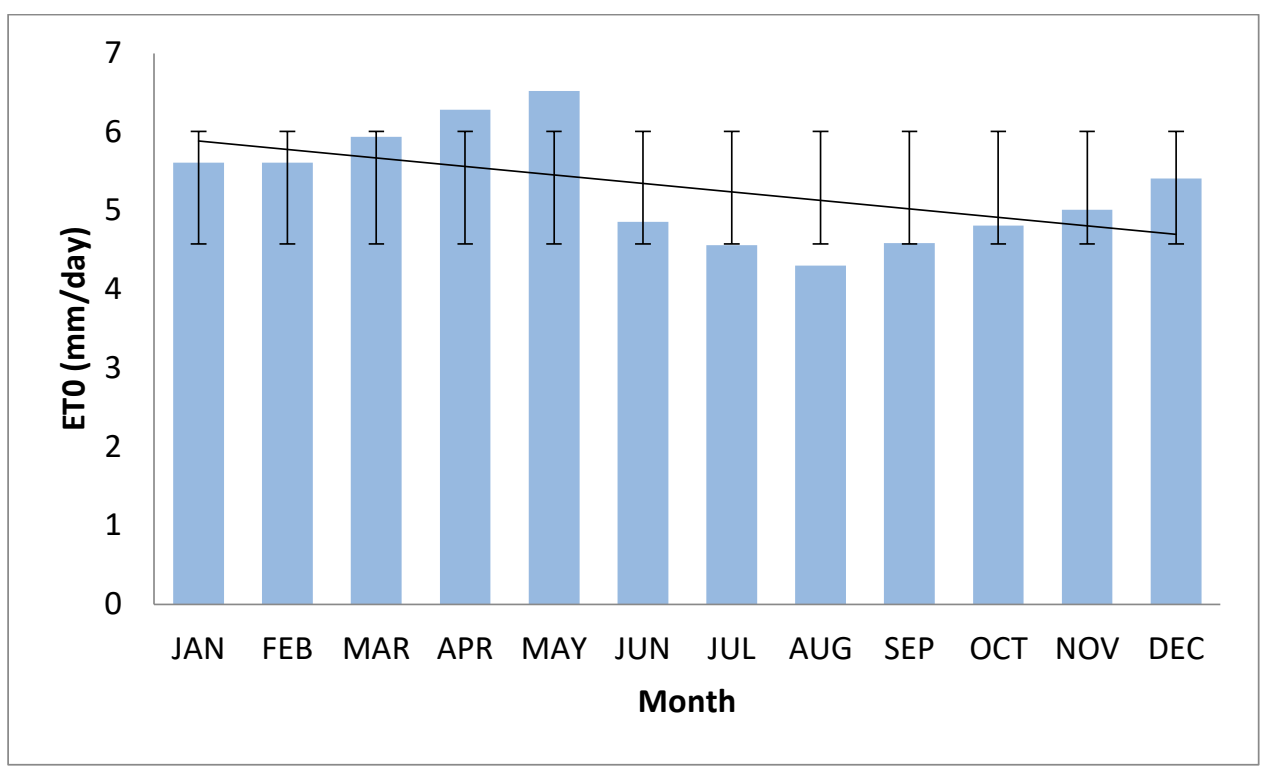

Figure 4: Gassol monthly evapotranspiration and standard deviation for 1987

Figure 5 is the chart for the estimated reference evapotranspiration for 1988. The minimum value of 3.79 mmday $^{-1}$ was in July while the maximum value of 6.45 mmday $^{-1}$ was in February, and the annual average of the $E T_{0}$ was 4.84 mmday $^{-1}$. The year also had a decreasing trend with the first half season having higher value than the second half season. This pattern is comparable to the estimates and analysis for the year 1998 as obtained in Figure 5.

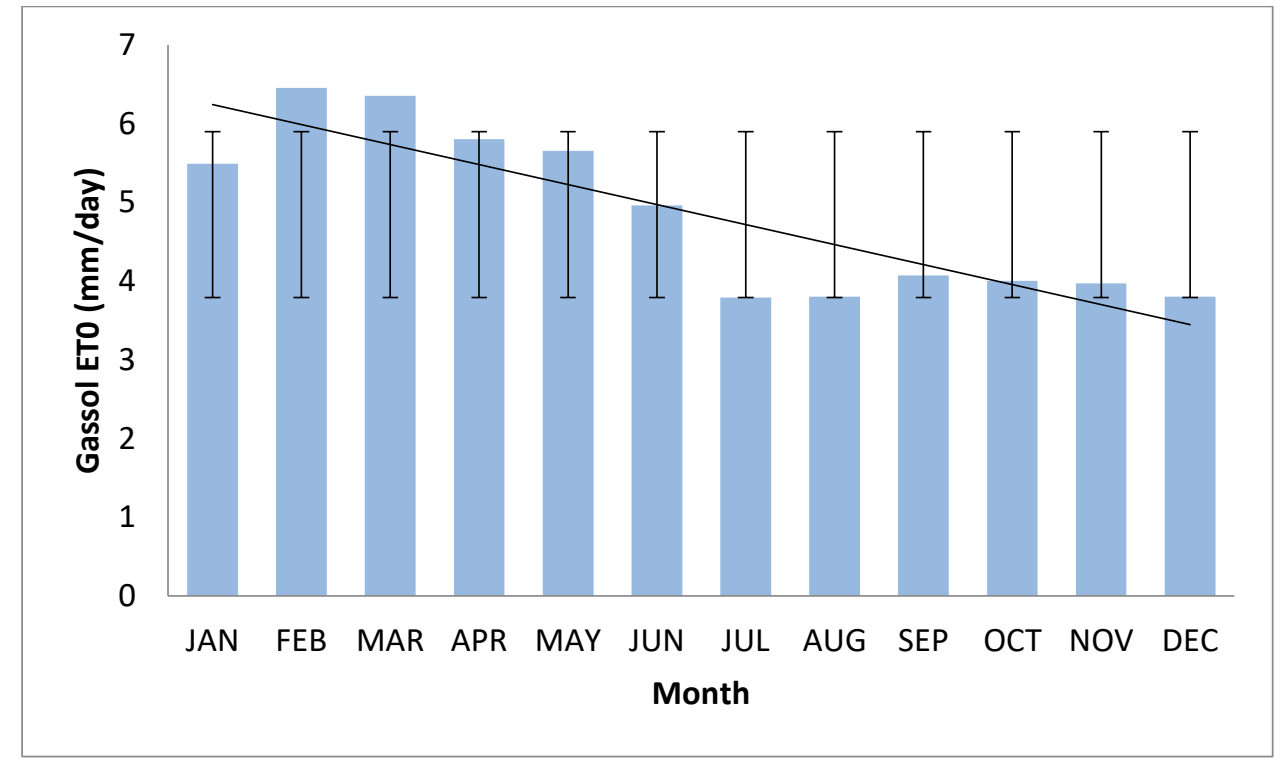

Figure 5: Gassol monthly evapotranspiration and standard deviation for 1988

Figure 6 is the 1989 estimated reference evapotranspiration for the study area. The month of October had the minimum value of 3.42 mmday $^{-1}$ while the month of February had the maximum with a value $6.46 \mathrm{mmday}^{-1}$, and the annual average $E T_{0}$ for the year was 4.74 mmday $^{-1}$. The first half had higher $E T_{0}$ than the second half of the year and had a decreasing trend as previous years. The months of October and November had deviations below the annual mean estimate. 


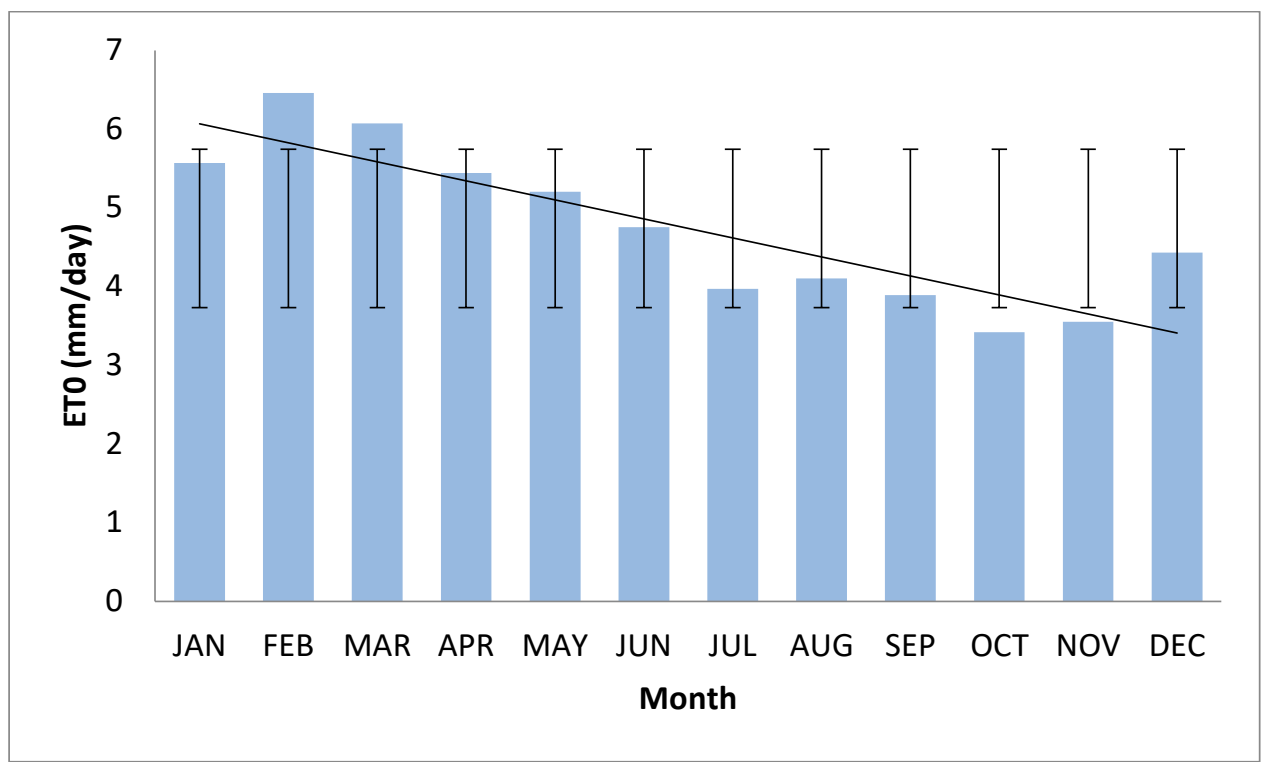

Figure 6: Gassol monthly evapotranspiration and standard deviation for 1989

Figure 7 is the 1990 estimated reference evapotranspiration chart. The minimum for the year was 3.39 mmday $^{-1}$ at the month of December while the annual maximum was $6.53 \mathrm{mmday}^{-1}$ at the month of April similar to Adeboye et al. (2009). The average $E T_{0}$ for the year was $4.92 \mathrm{mmday}^{-1}$. Generally, a decreasing gentle trend occurred with the first half of the year having higher values than the second half. The months of January and November had estimates below the mean annual estimate.

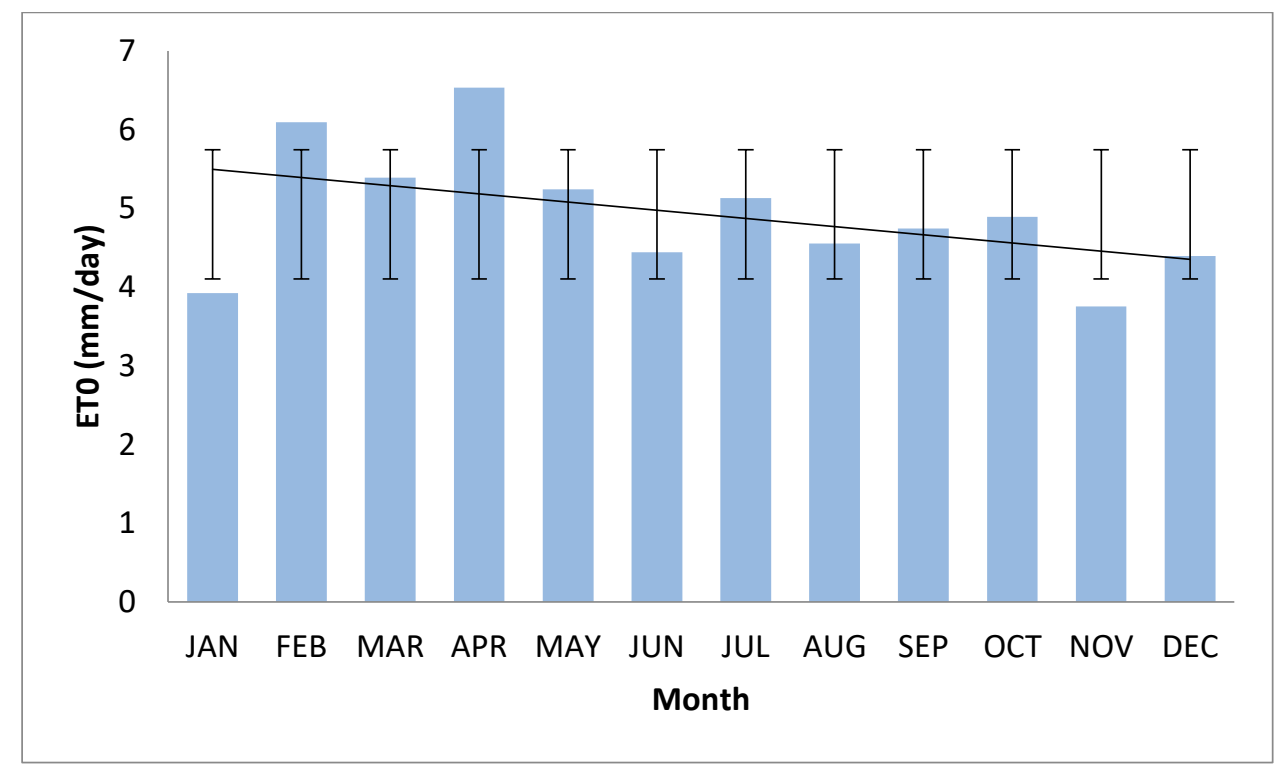

Figure 7: Gassol monthly evapotranspiration and standard deviation for 1990

Figure 8 is the estimated reference evapotranspiration for the year 1991. The minimum value of 3.34 mmday $^{-1}$ occurred at the month of July while the maximum value of 6.34 mmday $^{-1}$ occurred at the month of February, and the annual average was 4.69 mmday $^{-1}$. It had a steep decreasing trend as the first half of the year experienced higher $E T_{0}$ values than the second half of the year. July and December had deviations below the annual mean, as is seen in Edoga and Suzy (2008). The 1991 evapotranspiration for Gassol shows lower values for the months of May to August. This is attributed to lower temperature at the peak of the wet season. 


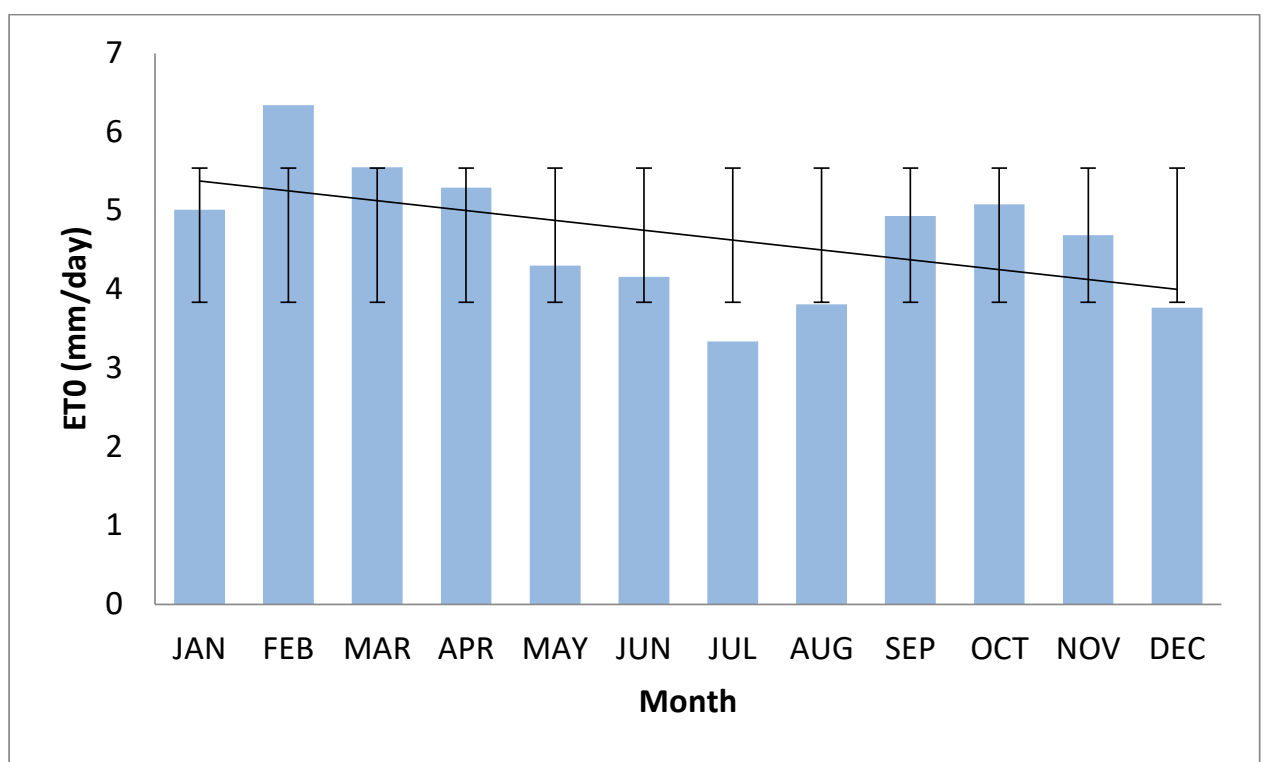

Figure 8: Gassol monthly evapotranspiration and standard deviation for 1991

Figure 9 is the time series chart of the estimated reference evapotranspiration for the study area. It covers $E T_{0}$ from 1985 to 1991 expressing a seasonal cyclical variability, with most years showing bimodal peaks. There was a general decreasing trend from year to year.

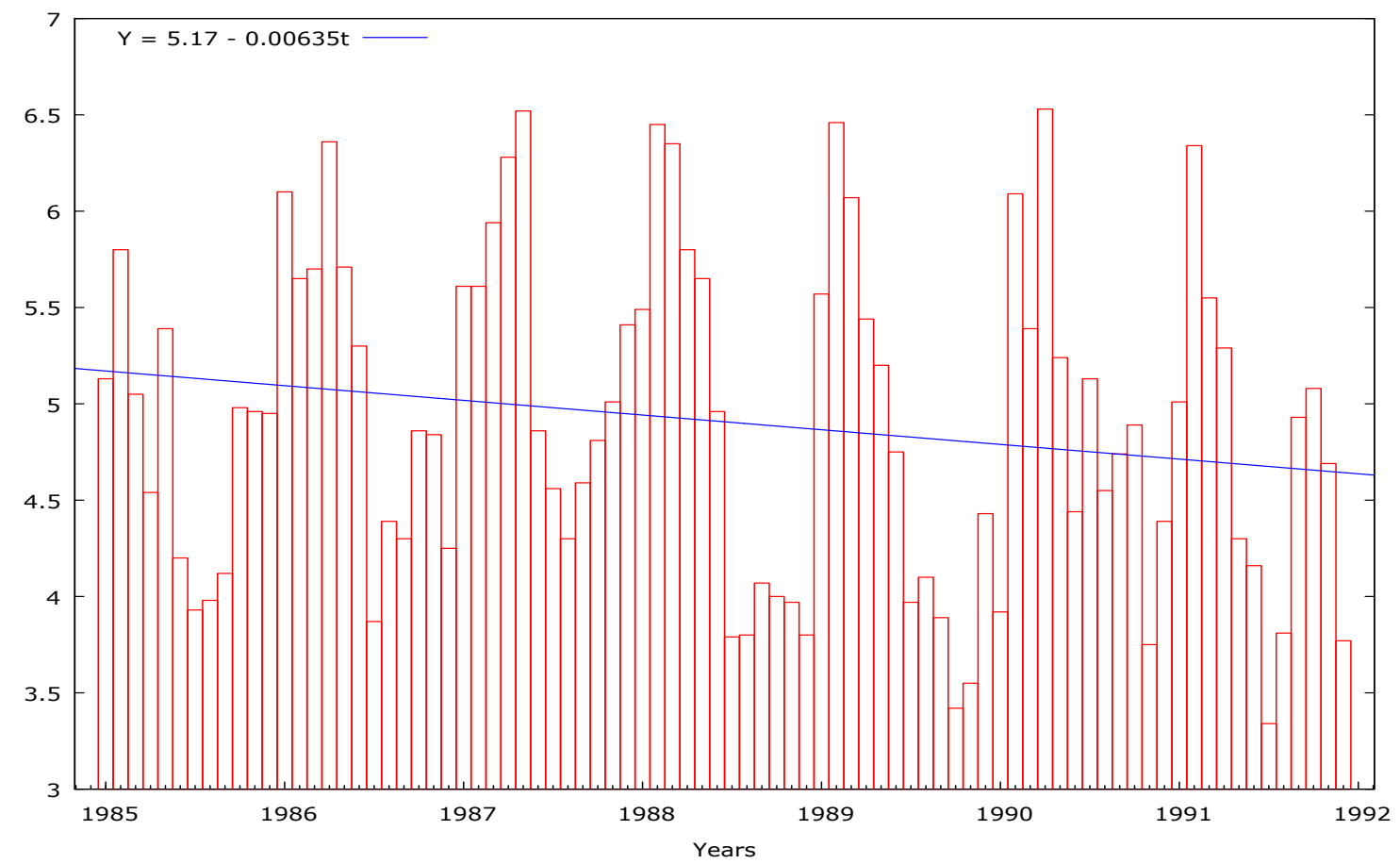

Figure 9: Gassol evapotranspiration (1985-1991)

Figure 10 is the frequency distribution of the reference evapotranspiration for Gassol. It shows an evenly spread data on the normal distribution curve. Figure 11 is the periodogram of Gassol reference evapotranspiration for the period 1985 to 1991. The dominant peak occurs at periodicity of 9.33 months. 


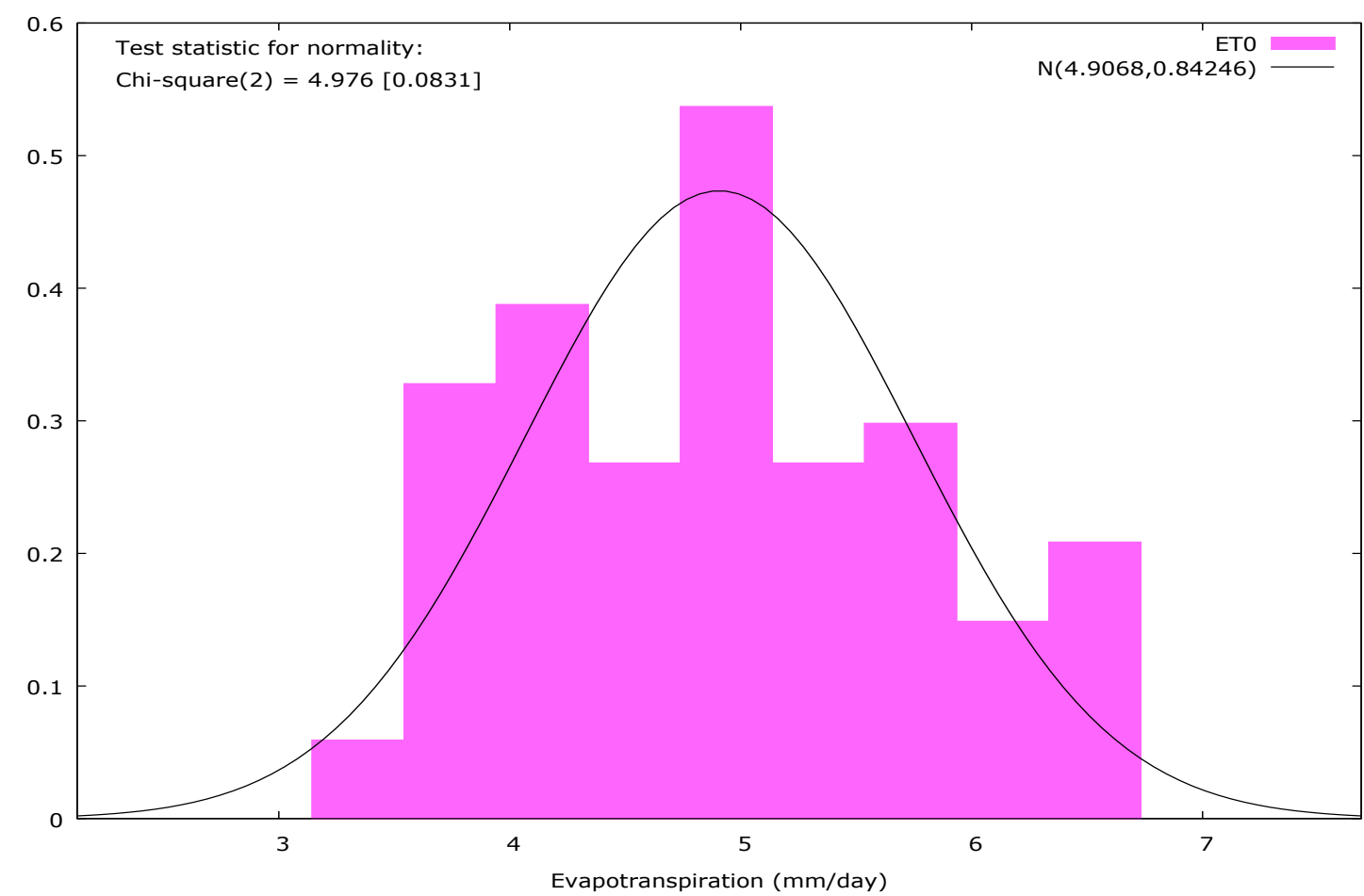

Figure 10: Gassol frequency distribution of evapotranspiration

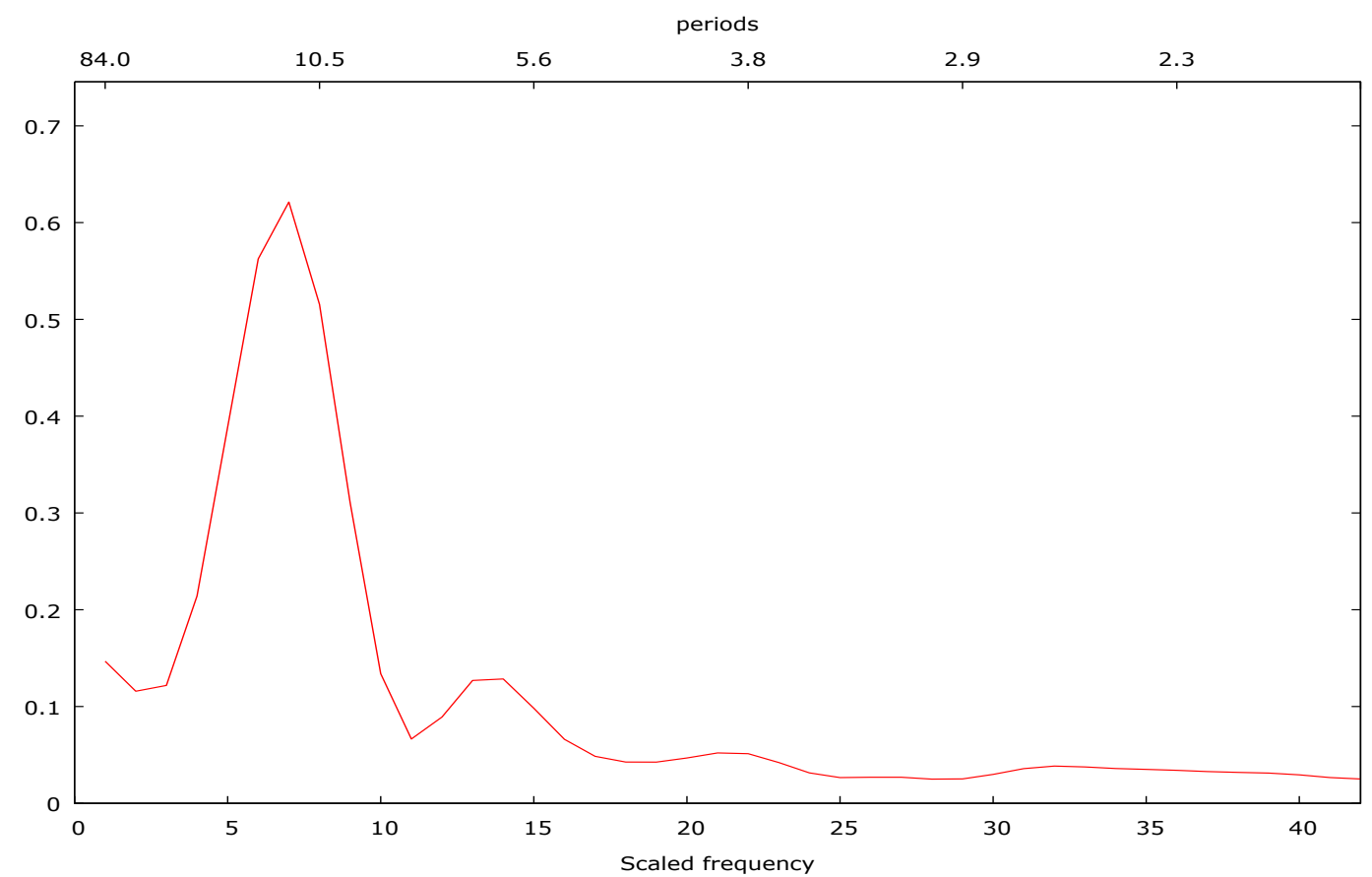

Figure 11: Gassol periodogram of evapotranspiration

\subsection{Conclusion}

The estimated values of reference evapotranspiration for Gassol from 1986 to 1991 generally had gentle decreasing trend. The first half of the years was of low values than the second half of the years. January-June estimates were more than the July-December values. For the monthly estimates the deviations experienced from the annual mean estimates were not significant to affect the accuracy of the estimates. The time series plot shows a near smooth pattern of variation with a generally decreasing trend. Knowledge of reference evapotranspiration is very important in micrometeorological applications, balance of energy over land surface and the effect of hydrology on climate change (Zhao, et al. 2013). Irrigation scheduling and water management are key agricultural practices that get properly done with a good understanding of the reference evapotranspiration of the area. There is the likelihood of further declining trend in subsequent years for the reference 
evapotranspiration in Gassol. There is the need for an efficient water management scheme through proper irrigation scheduling practices. January through March and October through December should be prioritized.

\section{References}

Abegunrin, T. P., Adegbola, S. O., Adejumobi, M. A., Awe G. O. Ojediran, J. O. and Ojo A. A. (2015). Soil hydrophobicity and crop evapotranspiration of two indigenous vegetables under different waste water irrigations in southwest Nigeria. African Journal of Agricultural Research, 10(5), pp. 365-372.

Adeboye, O.B., Osunbitan, J.A., Adekalu, K.O. and Okunade D.A. (2009). Evaluation of FAO-56 Penman-Monteith and Temperature Based Models in Estimating Reference Evapotranspiration. Agricultural Engineering International: the CIGR Ejournal, 11(1291), pp. 1-25.

Adekola, O., Bashir, A. and Kasimu, A. (2015). Physico-chemical characteristics of borehole water quality in Gassol Taraba State, Nigeria. African Journal of Environmental Science and Technology, 9(2), pp. 143-154.

Adeleke, O.O., Makinde, V., Eruola, A.O., Dada, O.F., Ojo, A.O. and Aluko, T.J. (2015). Estimation of Groundwater Recharges in Odeda Local Government Area, Ogun State, Nigeria using Empirical Formulae. Challenges, 6, pp. 271-281.

Alhassan, I., Ibrahim, A., Maunde, M.M. and Vahyala, I.E. (2015). Water requirement and irrigation schedule for tomato in northern guinea savanna zone. Nigeria Azarian Journal of Agriculture, 2(3), pp. 65-70.

Bernadette, I.C., Moses, A.O. and Martin I.O. (2014). Evaluation of Evapotranspiration using FAO Penman-Monteith Method in Kano Nigeria. International Journal of Science and Technology, 3(11).

Chineke, T.C., Idinoba, M.E. and Ajayi, O.C. (2011). Seasonal evapotranspiration signatures under a changing landscape and ecosystem management in Nigeria: Implications for agriculture and food security. American Journal of Scientific and Industrial Research, 2(2), pp. 191-204.

Edebeatu, C. C. (2015). Comparison of four empirical evapotranspiration models against the Penman - Montieth in a mangrove zone.Int. Journal of Applied Sciences and Engineering Research, 4(4), pp. 580-589.

Edebeatu, C. C., Okujagu, C. U., Ozuomba J. O., Owate, I. O. and Nwokocha C. O. (2014). Seasonal Calibration of the Hargreaves Equation for Estimating Monthly Reference Evapotranspiration in a Data Sparse Region. Merit Research Journal of Environmental Science and Toxicology, 2(4), pp. 076085 .

Edoga, R.N. and Suzy, A.B.U. (2008). Effect of Temperature Changes on Evapotranspiration in Minna, Niger State, Journal of Engineering and Applied Sciences, 3(6), pp. 482-486.

Edoga, R.N. (2007). Determination of Length of Growing Season in Samaru Using Different Potential Evapotranspiration Models, AU J.T. 11(1), pp. 28-35.

Eruola, A.O., Bello, N. J., Ufoegbune, G.C. and Makinde, A.A. (2012). Application of Rainfall Potential-Evapotranspiration Model for Determining Optimum Planting Date of Yam (DioscoreaRotundata) in a Tropical Wet-and-Dry Climate. Global Journal of Science Frontier Research Agriculture \& Biology, 12(5), pp. 52-58.

Ingale, P.M., Mohite, K.R. and Mahale, D.M. (2015). Determination of Reference Evapotranspiration of Harnai and Wakawalistation using FAO-56 Penman-Monteith model. Research Journal of Recent Sciences, pp. 481-486. 
Maina, M.M., Amin, M.S.M., Rowshon, M.K., Aimrun, W., Samsuzana, A.A. and Yazid, M.A. (2014). Effects of crop evapotranspiration estimation techniques and weather parameters on rice crop water requirement. Australian Journal of Crop Science, 8(4), pp. 495-501.

Ogolo, E.O. (2014). The Comparative Analysis of Performance Evaluation of Recalibrated Reference Evapotranspiration models for Different regional climatic conditions in Nigeria. Ife Journal of Science, 16(2), pp. 191-210

Rácz, C., Nagy, J., and Dobos, A.C. (2013). Comparison of Several Methods for Calculation of Reference Evapotranspiration, ActaSilv. Lign. Hung. 9, pp. 9-24.

Rauf, K.O. and Shittu, S.A. (2015). Determination of Evapotranspiration and Water Use Efficiency in Crop Production. Agricultural Sciences, 6, pp. 1058-1067.

Ufoegbune, G.C., Yusuf, H.O., Eruola, A.O. and Awomeso, J.A. (2011). Estimation of Water Balance of Oyan Lake in the North West Region of Abeokuta, Nigeria. British Journal of Environment \& Climate Change, 1(1), pp.13-27.

Umara, B.G., Aliyu, M.M., Umaru, A.B. and Abdullahi, A.S. (2012). Comparison of Four Empirical Models for Estimating Crop Evapotranspiration in Semi-Arid Nigeria. Australian Journal of Basic and Applied Sciences, 6(7), pp. 26-32.

Wang, Y.M., Traore, S. and Kerh, T. (2009). Computational performance of reference evapotranspiration in semiarid zone of Africa. Scientific Research and Essay, 4(6), pp. 577-583.

Zhao, L., Xia, J., Xu, C., Wang, Z., Sobkowiak, L. and Long, C. (2013). Evapotranspiration estimation methods in hydrological models, J. Geogr. Sci. 23(2), pp. 359-369. 